\title{
Colour preferences and awareness of home makers on the role of surface reflectance in enhaching lighting permormance in interior space
}

Mayur Rani Devi* and Ruplekha Borah Department of Family Resource Management, College of Home Science, Assam Agricultural University, Jorhat (Assam) India (Email : ruplekha_borah@rediffmail.com)

\section{ARTICLE INFO :}

$\begin{array}{lll}\text { Received } & : & 31.10 .2019 \\ \text { Revised } & : & 22.04 .2020 \\ \text { Accepted } & : & 18.05 .2020\end{array}$

KeY WORDS :

Colour preference,

Surface reflectance

\section{HOW TO CITE THIS ARTICLE :}

Devi, Mayur Rani and Borah, Ruplekha (2020). Colour preferences and awareness of home makers on the role of surface reflectance in enhaching lighting permormance in interior space. Adv. Res. J. Soc. Sci., 11 (1): 16-21, DOI: 10.15740/ HAS/ARJSS/11.1/16-21.Copyright@ 2020:Hind Agri- Horticultural Society

*Author for correspondence

\begin{abstract}
Light and colour are integral part of every residential interior. The present study was carried out to study the lighting, colour preferences and colour perception of house wives/ female respondents of residential units. A sample size of 60 female respondents from residential units was selected by purposive cum random sampling procedure from Jorhat district of Assam. Data were gathered by interview cum observation method. An attempt was made to identify the awareness of the respondents on the role of surface reflectance in enhancing lighting performance in interior space. An awareness scale was developed to determine awareness of the respondents on the role of surface reflectance in enhancing lighting performance in interior space. Finding pertaining to colour preferred and applied in selected activity areas reflected that majority of respondents preferred and used off white colour in walls of both living rooms (75\%) and kitchen $(81 \%)$. Maximum respondents $(70 \%)$ preferred and used off white colour in floors of living room while in kitchen 60 per cent preferred and used brown colour in floors. In both living room furniture (80\%) and kitchen cabinets (46.6\%), respondents mostly preferred and used brown colour. Awareness of the respondents on the role of surface reflectance in enhancing lighting performance in interior space was found to be average. Employed and highly educated female respondents had high awareness on the role of surface reflectance in enhancing lighting performance in interior space.
\end{abstract}

